\title{
Serum Prolactin Levels in Homosexual and Bisexual Men With HIV Infection
}

\author{
Jack M. Gorman, M.D., Patricia A. Warne, Ph.D., Melissa D. Begg, Sc.D., \\ Thomas B. Cooper, M.A., Hana Novacenko, M.S., Janet B.W. Williams, D.S.W., \\ Judith Rabkin, Ph.D., Yaakov Stern, Ph.D., and Anke A. Ehrhardt, Ph.D.
}

\begin{abstract}
Objective: Prolactin is a neurohormone that may be secreted in response to stress and also has regulatory effects on the immune system. Some, but not all, studies suggest that prolactin levels are higher than normal in persons with HIV infection. The authors measured prolactin levels in HIV-positive and HIV-negative homosexual and bisexual men to assess possible differences in levels and then examined relationships between prolactin level and measures of medical status, anxiety, depression, stress, and neuropsychological test performance. Method: Blood for prolactin level determination was obtained from $121 \mathrm{HIV}$-seropositive and $79 \mathrm{HIV}$ seronegative homosexual and bisexual men enrolled in a longitudinal study. The men also underwent a daylong assessment that included medical, immunological, psychiatric, psychosocial, psychosexual, and neuropsychological evaluations. Results: There was no statistically significant difference in serum prolactin level among the seronegative men, the seropositive men with no or minimal physical symptoms, and the seropositive men with significant physical symptoms of HIV infection. Furthermore, within the HIV-seropositive group, the correlations between serum prolactin level and measures of depression, anxiety, stress, and neuropsychological test performance were all nonsignificant. Conclusions: Serum prolactin level does not seem to respond to HIV infection or to be related to stress or psychiatric symptoms in HIV-infected men. As none of the subjects had AIDS, the possibility cannot be ruled out that prolactin level increases in very late stages of HIV infection.
\end{abstract}

(Am J Psychiatry 1992; 149:367-370)

$\mathrm{T}$ he human immunodeficiency virus (HIV) produces disruption in almost every aspect of immune function, ultimately leading to an inability to contain opportunistic infection and neoplastic cell growth. It is clear, however, that a variety of responses are mounted against HIV by the infected host and, at least in early stages, contain the virus's ability to create immunological collapse. Neuroendocrine factors are known to have a role in regulating immune function, and recent work has examined possible ways in which the hypothalamus and pituitary gland may respond to HIV infection.

Prolactin is one hormone of particular interest be-

Received April 4, 1991; revision received July 18, 1991; accepted Aug. 16, 1991. From the HIV Center for Clinical and Behavioral Studies, New York State Psychiatric Institute, and the Departments of Psychiatry and Neurology, College of Physicians and Surgeons, and Division of Biostatistics, School of Public Health, Columbia University, New York. Address reprint requests to Dr. Gorman, New York State Psychiatric Institute, 722 West 168th St., New York, NY 10032.

Supported by NIMH/NIDA grant MH-43520 to the HIV Center for Clinical and Behavioral Studies and by NIMH Research Scientist Development Award MH-00416 to Dr. Gorman.

Copyright 우 1992 American Psychiatric Association. cause it is believed to have significant interaction with immune function $(1-4)$ and may also be released during stress (5-8). High prolactin levels have also been implicated in panic disorder (9), psychosis (10), and alcoholism with psychosis (11). In all cases, the differences in prolactin level are modest.

A few studies have examined prolactin levels in patients with HIV infection. Croxson et al. (12) measured the prolactin levels of 85 homosexual men. The mean prolactin levels of patients with AIDS and patients with AIDS-related complex were significantly higher than that of seronegative men. The difference in prolactin level between asymptomatic HIV-positive and HIVnegative men was not significant. Nelson et al. (13) also found a higher mean prolactin level in a group of 48 HIV-infected men than in either a group of 13 HIVnegative homosexual men or a group of 14 men described by them as "normal heterosexuals." Three small studies (14-16) showed no relationship between prolactin level and HIV infection.

The literature therefore suggests that prolactin level may increase with increasing severity of HIV infection, and there are theoretical reasons to believe that prolac- 
tin level may increase with stress or psychiatric illness and play a role in immune function. As part of a longitudinal, multidisciplinary study of patients with HIV infection, we obtained blood for prolactin level determination from HIV-seropositive and HIV-seronegative homosexual and bisexual men during a baseline evaluation that included medical, immunological, psychiatric, psychosexual, and neuropsychological assessments. In our relatively large study group we looked for differences in prolactin level among groups stratified for degree of illness severity. Furthermore, we analyzed the data to determine relationships between prolactin level and measures of illness severity, stress, and psychiatric symptoms.

\section{METHOD}

\section{Subjects}

The subjects of this report are all enrolled in an ongoing study of HIV infection and are described in more detail elsewhere (17). When the study was initiated in 1988 , the cohort of homosexual and bisexual men included $123 \mathrm{HIV}$-seropositive and $84 \mathrm{HIV}$-seronegative subjects. One HIV-seropositive subject previously included in the cohort actually had AIDS at the baseline assessment according to information subsequently received and has therefore not been included here. The subjects are seen every 6 months for a daylong evaluation that includes medical history and physical examination, neurological examination, neuropsychological testing, and psychiatric and psychosexual interviews. Blood is obtained for lymphocyte subset analysis, serum p24 antigen level determination, and confirmatory HIV testing. Serum from every subject is then frozen. Urine is also obtained for 24 hours to determine urinary free cortisol level. All subjects signed informed consent statements before testing.

To be included in the study, a subject was required to have known his HIV status for at least 1 month and to have not used intravenous drugs more than 10 times since 1981. HIV-seropositive subjects at all stages of the illness were enrolled, but subjects who already had histories or evidence of opportunistic infection or secondary tumors that met the CDC National Surveillance Criteria for AIDS (18) were excluded.

Of the $123 \mathrm{HIV}$-seropositive and $84 \mathrm{HIV}$-seronegative men assessed at baseline, serum samples sufficient for prolactin level determination were available for 121 and 79, respectively. The mean ages of the two groups were not significantly different: 38.4 years $(S D=8.2)$ versus 37.5 years $(\mathrm{SD}=8.7)(\mathrm{t}=-0.71, \mathrm{df}=198, \mathrm{p}=0.48)$.

\section{Procedure}

The medical history was obtained from each subject by a research nurse who was not blind to HIV status and used a structured interview focusing on HIV-related symptoms. Although the physician who performed the physical examination followed a semistructured format that also focused on HIV-related signs, the physician was blind to the subject's HIV status. The stage of HIV infection was rated according to standard CDC criteria (19).

The numbers of $\mathrm{CD}^{+}+$and $\mathrm{CD} 8+\mathrm{T}$ lymphocytes in peripheral blood were determined with a fluorescent activated cell sorter on mononuclear cell populations.

Psychiatric examination was performed by a trained mental health professional who was not blind to HIV status. This assessment included the Structured Clinical Interview for DSM-III-R (SCID) (20) and a battery of rating scales. Here we report results on the Hamilton Rating Scales for Depression and for Anxiety (21), a demoralization scale from the Psychiatric Epidemiology Research Interview (PERI) of Dohrenwend (22), the Beck Hopelessness Scale (23), and a modified version of the Faschingbauer et al. Texas Revised Inventory of Grief (24). Further details on our use of these scales can be found elsewhere $(25,26)$.

Neuropsychological testing was performed by a trained technician blind to HIV status and included a battery of tests described in detail elsewhere (27). Performance on each test was compared to the norm for an age- and education-matched population and then rated as normal, borderline (at least one standard deviation below expected mean), or defective (at least two standard deviations below the expected mean). A clinical impression of neuropsychological performance (normal, borderline, or abnormal) was based on the consensus of two experienced neuropsychologists who reviewed the test scores independently and were blind to HIV status.

Serum prolactin levels were determined from stored frozen serum. The protocol called for blood to be obtained from each subject between 8:30 and 11:00 a.m. Occasionally, for technical and scheduling reasons, a blood sample was obtained from a subject later in the day, but no record of this was kept. The nurses responsible for phlebotomy reported that in more than $90 \%$ of the cases blood samples from this cohort were obtained in the morning and that any breaches in the protocol occurred at random with respect to the subjects' HIV status.

Serum prolactin was measured with double antibody radioimmunoassay (28). The prolactin standard (hPR1$\mathrm{RP}-1$ ) and the primary antiserum were donated by the $\mathrm{Na}$ tional Pituitary Agency (National Institute of Arthritis, Metabolism and Digestive Diseases). The 125I-labeled PR1 was repurified before use on a G-100 Sephadex column. Anti-rabbit-globulin serum was used to separate the bound and free fractions. The samples were assayed in duplicate. The intra- and interassay coefficients of variance were $6.37 \%$ and $6.86 \%$ at $3.8 \mathrm{ng} / \mathrm{ml}, 3.83 \%$ and $5.72 \%$ at $27.0 \mathrm{ng} / \mathrm{ml}$, and $2.01 \%$ and $3.49 \%$ at $46.3 \mathrm{ng} / \mathrm{ml}$.

To test for differences in serum prolactin level, we divided the subjects into three groups: HIV seronegative, HIV seropositive with no symptoms or only enlarged lymph nodes (CDC stages II and III), and HIV seropositive with more serious symptoms (CDC stages 
TABLE 1. T Cell Concentrations and Test Scores of HIV-Positive and HIV-Negative Homosexual and Bisexual Men

\begin{tabular}{|c|c|c|c|c|c|c|c|c|c|}
\hline \multirow[b]{3}{*}{ Variable } & \multicolumn{3}{|c|}{ HIV-Positive Men } & \multicolumn{3}{|c|}{ HIV-Negative Men } & & & \\
\hline & \multicolumn{2}{|c|}{$\begin{array}{c}\text { T Cell } \\
\text { Concentration } \\
\text { (cells/ } / \mu \mathrm{l}) \text { or } \\
\text { Test Score }\end{array}$} & \multirow[b]{2}{*}{$\mathbf{N}$} & \multicolumn{2}{|c|}{$\begin{array}{c}\text { T Cell } \\
\text { Concentration } \\
\text { (cells } / \mu \mathrm{l}) \text { or } \\
\text { Test Score }\end{array}$} & \multirow[b]{2}{*}{$\mathbf{N}$} & \multicolumn{3}{|c|}{ Significance } \\
\hline & Mean & SD & & Mean & SD & & $\mathrm{t}$ & df & $\mathrm{p}$ \\
\hline \multicolumn{10}{|l|}{$\mathrm{T}$ cell measure } \\
\hline $\mathrm{CD}^{+}$ & 409.0 & 222.6 & 120 & 843.1 & 263.7 & 79 & 12.50 & 197 & 0.000 \\
\hline $\mathrm{CD}^{+}$ & 829.0 & 435.3 & 120 & 549.9 & 202.6 & 79 & -5.33 & 197 & 0.000 \\
\hline CD4/CD8 ratio & 0.58 & 0.36 & 120 & 1.67 & 0.62 & 79 & 15.67 & 197 & 0.000 \\
\hline \multicolumn{10}{|l|}{ Tests } \\
\hline Hamilton depression scale & 4.25 & 4.16 & 120 & 3.16 & 3.51 & 79 & -1.91 & 197 & 0.06 \\
\hline Hamilton anxiety scale & 3.85 & 3.84 & 104 & 2.81 & 3.60 & 78 & -1.86 & 180 & 0.07 \\
\hline PERI demoralization scale & 28.22 & 14.90 & 117 & 24.00 & 13.09 & 78 & -2.03 & 193 & 0.04 \\
\hline Beck Hopelessness Scale & 5.42 & 4.94 & 116 & 3.21 & 3.16 & 78 & -3.50 & 192 & 0.001 \\
\hline Texas grief inventory & 29.33 & 10.98 & 108 & 28.90 & 10.18 & 77 & -0.27 & 183 & 0.79 \\
\hline Neuropsychologists' impression & 0.50 & 0.67 & 121 & 0.43 & 0.67 & 79 & -0.67 & 198 & 0.50 \\
\hline
\end{tabular}

IVa, IVb, IVc-2, and IVe). A three-group analysis of variance (ANOVA) was performed.

To test for a relationship between serum prolactin level and severity of HIV infection, we computed Pearson correlation coefficients within the HIV-positive group for the correlations between prolactin level and both number of $\mathrm{CD} 4+\mathrm{T}$ lymphocytes and ratio of $\mathrm{CD}^{+}$to $\mathrm{CD}^{+}+\mathrm{T}$ lymphocytes (CD4/CD8).

To test for a relationship between psychological state and prolactin level, we computed Pearson correlation coefficients for the relationship between prolactin level and scores on the Hamilton depression scale, Hamilton anxiety scale, PERI demoralization scale, Beck Hopelessness Scale, and Texas Revised Inventory of Grief within the HIV-positive group. Finally, we determined the correlation between prolactin level and score on the neuropsychologists' impression within the HIV-seropositive group.

All $\mathrm{p}$ values are two-tailed. The number of subjects varies among measures because of missing data.

\section{RESULTS}

Table 1 indicates that the HIV-positive patients had significantly fewer $\mathrm{CD} 4+\mathrm{T}$ cells, significantly more $\mathrm{CD} 8^{+}$ $\mathrm{T}$ cells, and a significantly lower $\mathrm{CD} 4 / \mathrm{CD} 8$ ratio. The HIV-positive subjects had significantly higher demoralization and hopelessness scores and nearly significantly higher anxiety and depression scores than the HIV-negative subjects. The clinical neuropsychological impression and grief scores were not significantly different.

Only six $(5 \%)$ of the HIV-positive subjects were taking zidovudine at the time of the baseline assessment, and we did not observe any relationship between zidovudine use and prolactin level in this small subgroup. Of other medications taken by the subjects in the study, only the antipsychotic drugs have, to our knowledge, a known effect on prolactin level. However, only two of the 121 HIV-positive men and one of the 79 HIV-negative men were taking these drugs.

Forty-seven $(39 \%)$ of the seropositive men were in
TABLE 2. Correlation of Prolactin Level With T Cell Concentrations and Test Scores for 12 HIV-Positive Homosexual and Bisexual Men

\begin{tabular}{lrcr}
\hline & \multicolumn{4}{c}{$\begin{array}{c}\text { Correlation With } \\
\text { Prolactin Level }\end{array}$} \\
\cline { 2 - 5 } Variable & $\mathrm{r}$ & $\mathrm{df}$ & $\mathrm{p}$ \\
\hline T cell concentrations & & & \\
CD4 & & & \\
CD4/CD8 ratio & -0.07 & 118 & 0.42 \\
Test scores & -0.15 & 118 & 0.11 \\
Hamilton depression scale & -0.07 & 118 & 0.44 \\
Hamilton anxiety scale & -0.08 & 102 & 0.41 \\
PERI demoralization scale & -0.06 & 115 & 0.54 \\
Beck Hopelessness Scale & -0.07 & 114 & 0.47 \\
Texas grief inventory & -0.01 & 106 & 0.88 \\
Neuropsychologists' impression & 0.10 & 119 & 0.26 \\
\hline
\end{tabular}

CDC stage II (asymptomatic), 28 (23\%) were in CDC stage III (enlarged lymph nodes), and $46(38 \%)$ were in CDC stage IVa, IVb, IVc-2, or IVe. The subjects were divided into three groups: 1) HIV-seronegative, 2) HIVseropositive-asymptomatic/lymphadenopathy, and 3) HIV-seropositive-symptomatic. Three-group ANOVA of serum prolactin level revealed no significant difference among these groups; the mean levels were 9.2 $(\mathrm{SD}=3.2), 10.2(\mathrm{SD}=3.4)$, and $9.9(\mathrm{SD}=3.9) \mathrm{ng} / \mathrm{ml}$, respectively $(\mathrm{F}=1.47, \mathrm{df}=2,197, \mathrm{p}=0.23)$.

Table 2 indicates that within the HIV-positive group the correlations between serum prolactin level and number of $\mathrm{CD}^{+} \mathrm{T}$ cells, CD4/CD8 ratio, anxiety, depression, demoralization, hopelessness, grief, and neuropsychological performance were all nonsignificant.

\section{DISCUSSION}

We did not find higher than normal prolactin levels or a significant correlation between severity of infection and prolactin level in our HIV-seropositive men. Furthermore, we did not observe any relationship between prolactin level and measures of anxiety, depression, or neuropsychological test performance. 
Like other groups of subjects (26), our group of HIVpositive subjects was relatively free of psychiatric illness at baseline, and none had AIDS. Without severely anxious, depressed, or medically ill individuals, we may have been limited in our ability to detect a relationship between psychological or medical state and prolactin level.

In an earlier report involving the same subjects (29), we found no significant difference between HIV-positive and HIV-negative homosexual and bisexual men in the level of 24-hour urinary free cortisol. The present findings on prolactin level are similar and, despite the cautions mentioned, suggest that prolactin level, like urinary cortisol level, is not altered in the earlier stages of HIV infection. Nevertheless, it is still conceivable that HIV, because it infects both the immune and the nervous systems, may disrupt normal relationships between neurohormones and immune function, as noted elsewhere (30). Future studies of prolactin's role in the immune response of HIV-infected patients should focus on more advanced stages of illness, functional measures of immune response (such as mitogen stimulation studies), and patient groups other than homosexual men.

\section{REFERENCES}

1. Russell DH, Kibler R, Matrisian L, Larson DF, Poulos B, Magun EB: Prolactin receptors on human $T$ and $B$ lymphocytes: antagonism of prolactin binding by cyclosporine. J Immunol 1985; 134: 3027-3031

2. Halper J: Immunocycte receptors and second messengers in psychoneuroimmunology, in Psychoimmunology Update. Edited by Gorman JM, Kertzner R. Washington, DC, American Psychiatric Press, 1991

3. Bernton EW, Meltzer MS, Holaday JW: Suppression of macrophage activation and T-lymphocyte function in hypo-prolactinemic mice. Science $1988 ; 239: 401-404$

4. Hiestand PC, Mekler P, Nordmann R, Grieder A, Permmongkol C: Prolactin as a modulator of lymphocyte responsiveness provides a possible mechanism of action for cyclosporine. Proc Natl Acad Sci USA 1986; 83:2599-2603

5. Meyerhoff JL, Oleshansky MA, Mougey EH: Psychologic stress increases plasma levels of prolactin, cortisol, and POMC-derived peptides in man. Psychosom Med 1988; 50:295-303

6. Jacobs S, Brown SA, Mason J, Wahby V, Kasl S, Ostfeld A: Psychological distress, depression and prolactin response in stressed persons. J Human Stress 1986; 12:113-118

7. Baumgartner A, Graf FJ, Kurten I: Prolactin in patients with major depressive disorder and in healthy subjects, III: investigation of basal and post-TRH prolactin during different forms of acute and chronic psychological stress. Biol Psychiatry 1988; 24: 286-298

8. Brooks JE, Herbert M, Walder CP, Selby C, Jeffecoate WJ: Prolactin and stress: some endocrine correlates of pre-operative anxiety. Clin Endocrinol (Oxf) 1986; 24:653-656

9. Cameron OG, Nesse RM: Systemic hormonal and physiological abnormalities in anxiety disorders. Psychoneuroendocrinology 1988; 13:287-307

10. Whalley LJ, Christie JE, Blackwood DH, Bennie J, Dick H, Blackburn IM, Fink G: Disturbed endocrine function in the psychoses, I: disordered homeostasis or disease process? $\mathrm{Br}$ J Psychiatry 1989; 155:455-461

11. Tsuchiya K: Studies on prolactin in major psychoses-with reference to prolactin response to stress in schizophrenia. Folia Psychiatr Neurol Jpn 1984; 38:53-56

12. Croxson TS, Chapman WE, Miller LK, Levit CD, Senie R, Zumoff B: Changes in the hypothalamic-pituitary gonadal axis in human immunodeficiency virus-infected homosexual men. J Clin Endocrinol Metab 1989; 68:317-321

13. Nelson R, Wright D, Russell D, Ledford D, Lockey R, Good R: Serum prolactin levels in patients with human immunodeficiency (HIV) infection, in Abstracts, V International Conference on AIDS, Montreal, 1989. Ottawa, International Development Research Centre, 1989

14. Merenich JA, McDermott MT, Asp AA, Harrison SM, Kidd GS: Evidence of endocrine involvement early in the course of human immunodeficiency virus infection. J Clin Endocrinol Metab 1990; 70:566-571

15. Dobs AS, Dempsey MA, Ladenson PW, Polk BF: Endocrine disorders in men infected with human immunodeficiency virus. Am J Med 1988; 84:611-616

16. Chernow B, Schooley RT, Dracup K, Napolitano LM, Stanford GG, Klibanski A: Serum prolactin concentrations in patients with acquired immunodeficiency syndrome. Crit Care Med $1990 ; 18: 440-441$

17. Gorman JM, Kertzner R, Todak G, Goetz RR, Williams JBW, Rabkin J, Meyer-Bahlburg HFL, Mayeux R, Stern Y, Lange M, Dobkin J, Spitzer R, Ehrhardt AA: Multidisciplinary baseline assessment of homosexual men with and without human immunodeficiency virus infection, I: overview of study design. Arch Gen Psychiatry 1991; 48:120-123

18. Classification system for human T-lymphotropic virus type III/ lymphadenopathy-associated virus infections. MMWR 1986; 35:334-339

19. Revision of the CDC surveillance case definition for acquired immunodeficiency syndrome. MMWR 1987; 36(suppl 1):1S-15S

20. Spitzer R, Williams JBW, Gibbon M, First MB: Structured Clinical Interview for DSM-III-R-Nonpatient Version for HIV Studies (SCID-NP-HIV). New York, New York State Psychiatric Institute, Biometrics Research, 1988

21. Williams JBW: Structured Interview Guide for the Hamilton Anxiety and Depression Rating Scales (SIGH-AD). New York, New York State Psychiatric Institute, Biometrics Research, 1988

22. Dohrenwend BP, Link B, Kern R, Shrout PE, Markowitz JR: Measuring life events: the problem of variability within event categories. Stress Med 1990; 6:179-187

23. Beck AT, Weissman A, Lester D, Trexler L: The measure of pessimism: the Hopelessness Scale. J Consult Clin Psychol 1974; 42: 861-865

24. Faschingbauer TR, Devaul RA, Zisook S: Development of the Texas Inventory for Grief. Am J Psychiatry 1977; 134:696-698

25. Rabkin JG, Williams JBW, Remien RH, Goetz R, Kertzner R, Gorman JM: Depression, distress, lymphocyte subsets and human immunodeficiency virus symptoms on two occasions in HIV-positive homosexual men. Arch Gen Psychiatry 1991; 48: 111-119

26. Williams JBW, Rabkin JG, Remien RH, Gorman JM, Ehrhardt AA: Multidisciplinary baseline assessment of homosexual men with and without human immunodeficiency virus infection, II: standardized clinical assessment of current and lifetime psychopathology. Arch Gen Psychiatry 1991; 48:124-130

27. Stern Y, Marder K, Bell K, Chen J, Dooneief G, Goldstein S, Mindry D, Richards M, Sano M, Williams J, Gorman J, Ehrhardt A, Mayeux R: Multidisciplinary baseline assessment of homosexual men with and without human immunodeficiency virus infection, III: neurologic and neuropsychological findings. Arch Gen Psychiatry 1991; 48:131-138

28. Sinha YN, Selby FW, Lewis UJ, Vanderlaan WP: A homologous radioimmunoassay for human prolactin. J Clin Endocrinol Metab $1973 ; 36: 509-516$

29. Gorman JM, Kertzner R, Cooper T, Goetz RR, Lagomasino I, Novacenko H, Williams JBW, Stern Y, Mayeux R, Ehrhardt AA: Glucocorticoid level and neuropsychiatric symptoms in homosexual men with HIV infection. Am J Psychiatry 1991; 148:41-45

30. Kertzner R: Future direction for psychoimmunology: HIV infection and beyond, in Psychoimmunology Update. Edited by Gorman JM, Kertzner R. Washington, DC, American Psychiatric Press, 1991 